\title{
EDTAによる鉛の定量法
}

\author{
久田 正典，柏川 嘉一*
}

\begin{abstract}
迅速にして精度の高い鉛分析法を導入するため実験をおてない目的を達したので報告する，試料を硝 酸, 硫酸で分解し硫酸鉛觉こしわけたのち酢酸一酥酸アンモ二ウム抽出液に溶解しふたたびてしわけ, 口液䎲 $\mathrm{Cu}-\mathrm{PAN}$ 指示薬を加えて煮沸し EDTA 標準溶液により滴定し, 紅色が最後の 1 滴で黄色にな る点を終点として鉛觉定量した。な打ての方法では滴定は酸性でおてなうから，被滴定液中にカルシウ ムが共存しても影響なかった。バリウムが含有される試料では結果は低くなるので，あらかじめ鉛と分 離する必要がある。鉱石試料扔上び鉛製煉関係試料に応用し,従来のクロム酸鉛法と比較して分析精度， 正確度うよく, 分析所要時間は $2 \sim 3$ 時間ですみ, 操作うきわめて簡単で良好な結果が得られた。
\end{abstract}

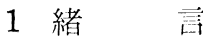

鉛の容量分析法にはクロム酸鉛法 (JIS ${ }^{1)}$ ) およびモり ブデン酸アンモニウム汒22)などがあり，クロム酸鉛法は すべての試料に嗔用でき，かつ正確な優れた方法でもっ とも広く採用されているが，操作にやや長時間を要与る 次点がある・モリブデン陻アンモニウム法は簡単である が，滴定に外部指示薬堂必要と与るため滴定操作が困難 である・このような理由から現場の操業管理上簡便过速 でしかも正確な分析泣が要望されてきた。

迅速分析洁の一つとしてキレート滴定法が考えられ, EDTA 芫用いた多くの研究3)4 が報告されている。筆

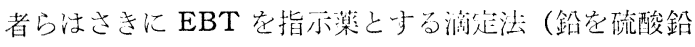
として分湤したの号, 酶酸アンモニウムに溶解し, 鉛の 沈殿を防ぐた酒不酸を加え，つぎにアンモニアを加え て pH 空約 10 とし, EBT を指示薬として EDTAで 滴定尗る）を鉱石，その他の試料に応用するため基礎実 験を抢こない满足すべき結果を得たので日常分析適用 実施してきたが，最近酸性で金属イオンの滴定に優れた 性質を持つ試薬として現われた $\mathrm{PAN}^{5}$ に少量の $\mathrm{Cu}$ EDTA を加えた指示薬 $\mathrm{Cu}-\mathrm{PAN}$ が EBT 指示薬より 優れていると報じられている6). よってさらに進んで $\mathrm{Cu}-\mathrm{PAN}$ 指示薬を用いる䈍碟実駼をおこない，鉱石お よび鉛製煉関係試料に応用したところ，EBT 指示薬よ り終点の变色は鋭敏かつ明暸であり, 滴定は酸性で抢こ なうためカルシウムの共存法影響なく, クロム酸鉛法と 比較してきわ和て迅速であり, 分析精度, 正確度もよく, 鉛の定量法として满足し得るものであることがわかった ので報告方る。

\footnotetext{
* 三菱金属鉱業怢明延鉱業所 : 兵庫県朝来郡朝来町
}

\section{2 試薬}

（1）鉛標準溶液：純金属鉛 $2.5 \mathrm{~g}$ 觉正確に秎量し， 硝酸 (1:3) $50 \mathrm{~m} l$ に溶解し, 正確に $500 \mathrm{~m} l$ となし, $1 \mathrm{ml} 5 \mathrm{mg}$ 鉛相当液をつくった.

（2）EDTA 標準溶液: 特級 EDTA $9.0 \mathrm{~g}$ を純水 に溶解し $1 l$ と方. 本標準溶液 $1 \mathrm{~m} l$ は約 $5 \mathrm{mg}$ の鉛 に相当する・標準液の力伍法純鉛で標定する.

(3) $\mathrm{Cu}-\mathrm{PAN}$ 指示薬液: $\mathrm{Cu}-\mathrm{PAN}$ 指示薬 $0.2 \mathrm{~g}$ を $50 \%$ イソプロピルアルコール $10 \mathrm{~m} l$ に溶解する. 実 際に浣全に溶けないので飽和溶液の上澄液觉用いる。

(4) 酢酸アンモ二ウム抽出液(JIS 組成) : 酶酸アン モニウム $250 \mathrm{~g}$ 篮純水に溶解し全量を $1 l$ とし, これに 氷酷酸 $25 \mathrm{~m} l$ を加える.

（5） その他の試薬 : 酒石酸, 硝酸, 硫酸はいずれも 一級品を使用した。

\section{3 基礎 実験}

\section{$3 \cdot 1$ 滴定液の $\mathrm{pH}$ の影響}

滴定時液の $\mathrm{pH}$ は交献には 3〜3.5 がよいとなってい るが鉛を硫酸鉛として分離し，こ水を溶解するには酶酸 アンモニウムを用いるので $\mathrm{pH}$ を酶酸アンモニウムと酢 酸で調整し，そのときの $\mathrm{pH}$ の変化による影響を実験し た. 鉛 $50 \mathrm{mg}$ 相当量をとり硫酸を加えて加熱し硫酸の 白煙を発生させる. 冷後水を加えて加温し室温泠却寸 る. 硫酸鉛定こLわ河冷希硫酸洗液 $(1: 10)$ で洗浄し, 沈殿をもとのビーカーに洗い落し $25 \%$ 酰酸アンモニウ 厶溶液 $30 \mathrm{~m} l$ を加えて煮沸し硫酸鉛を完全に溶解する. つぎに，もとの口紙を用いてこしわけ洗浄する， 口液に Table I の上うに氷酶酸を加え液量を $150 \mathrm{ml}$ とし, 
$\mathrm{pH}$ を測定し $\mathrm{Cu}-\mathrm{PAN}$ 指示薬を加えて煮沸し EDTA 標準溶液で滴定した．終点注紅色 $\rightarrow$ 黄色である.その結 果は, Table I に示すとおりで $\mathrm{pH}$ 4〜7 において明 瞭な終点が得られ，結果もよくあうことがわかった。 pH 4 以下で注終点は不明瞭で滴定できない。 JIS 法に 用いられる酢酸一酷酸アンモニウム抽出液で抽出した鉛 の溶液は $\mathrm{pH}$ が大体 5 以上であるのでこの抽出液を用い ることにした。

Table I pH の変化による影響

\begin{tabular}{|c|c|c|c|c|}
\hline $\begin{array}{r}\text { 添加鉛 } \\
(\mathrm{mg})\end{array}$ & $\begin{array}{c}25 \% \\
\text { 酢酸アンモ } \\
(\mathrm{m} l)\end{array}$ & $\begin{array}{l}\text { 氷酰酸 } \\
(\mathrm{m} l)\end{array}$ & $\mathrm{pH}$ & $\begin{array}{l}\text { EDTA } \\
\text { 滴定数 } \\
(\mathrm{ml})\end{array}$ \\
\hline 50 & 30 & 0 & 7.25 & 10.40 \\
\hline "I & "I & 0.5 & 5.72 & 10.45 \\
\hline "I & " & 2.5 & 5.12 & 10.50 \\
\hline "I & "I & 10.0 & 4.45 & 10.40 \\
\hline$/ \prime$ & "I & 30.0 & 3.94 & 10.30 \\
\hline "I & $" \prime$ & 60.0 & 3.62 & 終点不明瞭 \\
\hline
\end{tabular}

\section{$3 \cdot 2$ 酢酸アンモニゥム抽出液の添加量の影響}

酶酸アンモニウム抽出液 (JIS1) 組成) の添加量の影響 を実験したところ 10〜 $60 \mathrm{ml}$ の間において影響ないこと がわかった。

\section{$3 \cdot 3$ 滴定液量の影響}

滴定時の液量の変化について試験したがほとえど影響 ない. 大体に㧍いて $100 〜 200 \mathrm{ml}$ の間で滴定すればよ W.

\section{$3 \cdot 4$ 滴定温度の影響}

常温では反応速度が遅く終点は不明瞭で過剩のEDTA を消費し滴定できない.したがって高温で滴定すること が必要である.すなわ台指示薬を加えたのち 1 分間 煮沸しただちに滴定する。なおＥDTAを多量に消費す る場合は途中で 1 度加熱し温度を保持することが必要で ある.

\section{$3 \cdot 5$ 鉛量と EDTA 滴定数との関係}

鉛量と EDTA 標準溶液の滴定 $\mathrm{ml}$ 数との関係を実験 したところ，鉛 $400 \mathrm{mg}$ まではほぼ直線的相関関係に あり，したがって比較的高品位の鉛試料にいたるまで広 範囲に定量できることがわかった。

\section{$3 \cdot 6$ 共存金属の分離および影響}

$3 \cdot 6 \cdot 1$ 鉛亡他金属の分離 EDTA は単一金属の場 合汢滴定法により簡単に定量できるが，非常に広い範囲 の金属イオンと安定な金属キレート化合物を生成するた
めに，応用範囲が広い半面選択性にかけるから滴定液中 の共存金属イオンに対しては特別の考虑が必要である. 鉛を硫酸鉛として沈殿させることによりケイ酸，バリウ ム，カルシウム拉よ゙タングステン以外のほとえどすべ ての金属と分離ができるわけである.しかし多量のアン チモン，ビスマス，スズおよび銀などの金属が含有され る場合硫酸鉛とともに沈殿，または混入される・よって 一応硫酸による主要金属と鉛の分離实験を打こなった。 鉛 $50 \mathrm{mg}$ 相当量をとりこ机に他金属を Table II のと おり加え，つぎに硫酸を加えて加熱し硫酸の白煙を強く 発生させる. 冷後水它加えて加温し室温に泠却する. 硫 酸鉛をこしわけ冷希硫酸洗浄液 $(1: 10)$ で洗浄し, 沈殿 はもとのビーカーに洗い落し酰酸アンモニウム抽出液で 溶解し, もとの口紙を用いてこしわけ洗浄する. 口液を $200 \mathrm{ml}$ となし Cu-PAN 指示薬を加えて竟沸し EDTA 標準溶液で滴定した.なおアンチモンは硫酸塩としたの ち水に溶解すると沈殿堂生ずるので酒不酸を加えて溶解 した。 またスズは同じく硫酸增を水に溶解して強く加温 すると沈殿を生じ酶酸アンモニウム抽出液で完全に鉛を 溶解することができないのでわずか加温して沈殿を生じ ないようにして抢こなった。その結果は Table II に示 すとおりタングステン以外ほとえどすべての金属は誤差 範囲内で分離できることがわかった．タングステンの結 果がきわめて低くなったのはタングステンの沈殿に鉛が つつみ込まれて酶酸アンモニウム抽出液で鉛の抽出が不 完全になるためと考えられる・したがってタングステン を含有する場合は初め塩酸, 硝酸でタングステンを沈殿 させてこしわけ口液に硫酸を加えて硫酸塩とし, 硫酸鉛 を沈殿させることが必要である。

Table II 鉛（添加量 $50 \mathrm{mg}$ ) と他金属の分離

\begin{tabular}{lcccc}
\hline $\begin{array}{c}\text { 金属添加量 } \\
(\mathrm{mg})\end{array}$ & $\begin{array}{c}\text { EDTA 滴定数 } \\
(\mathrm{m} l)\end{array}$ & $\begin{array}{c}\text { 鉛測定值 } \\
(\mathrm{mg})\end{array}$ & $\begin{array}{c}\text { 誤 } \\
(\mathrm{mg})\end{array}$ \\
\hline $\mathrm{Cu}$ & 1000 & 10.40 & 50.00 & 0 \\
$\mathrm{Zn}$ & 1000 & 10.35 & 49.76 & -0.24 \\
$\mathrm{Fe}$ & 1000 & 10.35 & 49.76 & -0.24 \\
$\mathrm{Mg}$ & 500 & 10.45 & 50.24 & +0.24 \\
$\mathrm{~A} 1$ & 300 & 10.40 & 50.00 & 0 \\
$\mathrm{Mn}$ & 300 & 10.45 & 50.24 & +0.24 \\
$\mathrm{As}$ & 300 & 10.40 & 50.00 & 0 \\
$\mathrm{Bi}$ & 300 & 10.40 & 50.00 & 0 \\
$\mathrm{Sb}$ & 200 & 10.50 & 50.48 & +0.48 \\
$\mathrm{Cd}$ & 200 & 10.30 & 49.52 & -0.48 \\
$\mathrm{Ni}$ & 200 & 10.60 & 50.96 & +0.96 \\
$\mathrm{Co}$ & 200 & 10.60 & 50.96 & +0.96 \\
$\mathrm{Cr}$ & 200 & 10.40 & 50.00 & 0 \\
$\mathrm{Sn}$ & 200 & 10.35 & 49.76 & -0.24 \\
$\mathrm{Mo} \cdot 200$ & 10.30 & 49.52 & -0.48 \\
$\mathrm{Ag}$ & 100 & 10.35 & 49.76 & -0.24 \\
$\mathrm{WO}$ & 200 & 10.40 & 50.00 & 0 \\
\hline & & 0.90 & 4.33 & -45.67 \\
\hline
\end{tabular}


$3 \cdot 6 \cdot 2$ カルシゥム共存の影響カルシウムは硫酸 で硫酸カルシウムを沈殿するが，溶解度がかなり大きい のである程度のカルシウム苍含有しても沈殿を水に溶解 したとき硫酸鉛から分離できる、しかし多量に含有する と鉛とともに滴定液中に共存されるのでその影響実験を おこなった、酶酸アンモニウム抽出液で抽出した鉛溶 液に酷酸カルシウム溶液を Table III のと打り加え, EDTA 標準溶液で润定した。その結果は Table III に 示声と抢りで，カルシウムは酸性で EDTA と反応しな いので約 $300 \mathrm{mg}$ までカルシウム分共存してもほとえど 影響ないことがわかった. $400 \mathrm{mg}$ では終点がやや不明 瞭となり絬果涼くなった、交执カルシウムが多くなる にしたがって結果はわずかずつ高くなる傾向がある。

Table III カルシウム共存の影響

\begin{tabular}{ccccc}
\hline $\begin{array}{c}\text { 添加鉙 } \\
(\mathrm{mg})\end{array}$ & $\begin{array}{c}\text { 添加カルシウム } \\
(\mathrm{mg})\end{array}$ & $\begin{array}{c}\text { EDTA 滴定数 } \\
(\mathrm{m} l)\end{array}$ & $\begin{array}{c}\text { 測定鉛 } \\
(\mathrm{mg})\end{array}$ & $\begin{array}{c}\text { 誤 差 } \\
(\mathrm{mg})\end{array}$ \\
\hline 50 & 20 & 10.35 & 49.76 & -0.24 \\
$\prime \prime$ & 50 & 10.40 & 50.00 & 0 \\
$\prime \prime$ & 100 & 10.50 & 50.48 & +0.48 \\
$\prime \prime$ & 200 & 10.55 & 50.72 & +0.72 \\
$\prime \prime$ & 300 & 10.65 & 51.20 & +1.20 \\
$\prime \prime$ & 400 & $10.90 \dagger$ & 52.40 & +2.40 \\
\hline
\end{tabular}

$\dagger$ 終点やや不明暸

\section{$3 \cdot 6 \cdot 3$ バリウムの影響陚料中にバリウムが共存} 寸叔硫酸により硫酸バリウムを沈殿し，これは酶酸ア ンモニウムにとけない。したがってバリウムが共存する と硫酸鉛注酢酸アンモニウムに完全に溶解されない。と くにバリウムが鉛に比し多くなるとこの傾向がいちじる しくそのた放絬果注低くなると考元られる。そ机でバリ ウム共存の影響をしらべた・鉛抒よびバリウムを Table IV に示寸ようにとり硫酸を加兑て加熱し以下 $3 \cdot 6 \cdot 1$ の と打り抢こないEDTA で鉛索滴定した。年の結果は Table IVに示与と抢りでいずれも低い結果を示しバリ ウムが多い注どその差は大きくなった。 バリウムを含有 する試料汇対しては鉛学硫化水素分離宗たは電解分離定 おこなったのち本分析法を適用しなければならない。

Table IV バリウムの影響

\begin{tabular}{ccccc}
\hline $\begin{array}{c}\text { 添加鉛 } \\
(\mathrm{mg})\end{array}$ & $\begin{array}{c}\text { 添加ハリウム } \\
(\mathrm{mg})\end{array}$ & $\begin{array}{c}\text { EDTA 滴定数 } \\
(\mathrm{m}) \text { 測定鉛 }\end{array}$ & $\begin{array}{c}\text { 誤 差 } \\
(\mathrm{mg})\end{array}$ \\
\hline 50 & 10 & 7.80 & 37.50 & -12.50 \\
$\prime \prime$ & 20 & 6.30 & 30.89 & -19.11 \\
$\prime \prime$ & 50 & 2.80 & 13.46 & -36.54 \\
$" \prime$ & 100 & 1.70 & 8.17 & -41.83 \\
$" \prime$ & 150 & 1.00 & 4.81 & -45.19 \\
\hline
\end{tabular}

\section{4 定量方法}

基礎実験の検討にもとゔき各種の試料に応用した結果 つぎのような定量法を設定した。

第 1 法 細粉試料 $0.5 \sim 1 \mathrm{~g}$ をビーカーにはかりと り, 硝酸(比重約 1.40) $10 \sim 15 \mathrm{ml}$ 艺徐々に加光て加温し 溶解させる.はぼしい反态が終れば硫酸（比重約 1.84） $20 \mathrm{~m} l$ 它加光強熱して硫酸の白煙を発生さ也る。これに アンチモンなどを還元させるた为に口紙の小片（通常 9 $\mathrm{cm}$ の口紙の $1 / 8$ 1/16 党用いる）䘮投入し加熱をつゔ け溶液が浪とえぞ無色になるまで強熱する。つぎに熱溶 液に硝酸（比重 約 1.40）の数滴を加えてロ紙および他 の有機物質を分解し，ふたたび少時間加熱し硫酸の白煙 を十分に発生させて硝酸学駆逐寸る.放冷後水約 $100 \mathrm{ml}$ を用いてビーカーの内壁を洗い，つぎ酒石酸約 $2 \mathrm{~g}$ 加え加温して静加に煮沸し可溶性塩を完全に溶解したの ち室温に冷却する・冷後ちみつな口紙を用いて沈殿など をこしわけ, 冷希硫酸洗浄液 $(1: 10)$ を用いて十分に洗浄 し, 温湯を用いてもとのビーカーに洗い落し温酶酸アン モニウム抽出液 $30 \sim 40 \mathrm{~m} l$ を加光徐熱して静かに煮沸さ せ, 硫酸鉛を完全に溶解し,もとの口紙を用いてビーカー にこしわける。紙および不溶解残サ温湯它用いて十 分に洗浄し口液を 150〜 $200 \mathrm{ml}$ とする. 口液に $\mathrm{Cu}-\mathrm{PAN}$ 指示薬溶液 8 10 滴を加え煮沸乙 EDTA 標準溶液を用 い紅色が最後の 1 滴で黄色になる点を終点とし鉛を定量 する。

第 2 法（迅速法） 本法酒酸分解した不溶解残 サ (主としてケイ酸およびケイ酸塭)をこしわけることなく 操作寸るもので, 滴定液中白色不溶解物が存在するの で多少滴定に不便を感じるが，口過操作を 1 回省略した 迅速な方法で亦る。

細粉試料 $0.5 \sim 1 \mathrm{~g}$ をビーカーにはかりとり，第 1 法 と同様分解し硫酸鉛をこしわ汀洗浄し, 沈殿をもとのビ 一カーに洗い落し, 口トの下に受け, 口紙上より沸騰し た酶酸アンモニウム抽出液 $30 \sim 40 \mathrm{ml}$ を加光, 口悢任付 着した硫酸鉛を完全に溶解し洗浄する。液量を150～200 $\mathrm{m} l$ に希勫し, $\mathrm{Cu}-\mathrm{PAN}$ 指示薬溶液 8１0 滴を加光堂 沸し第 1 法と同様 EDTA 標準溶液を用いて滴定する.

\section{5 定量結果}

上記定量方法汇より鉱石試料沶よび鉛製㷄関係試料に 適用乙鉛の分析品位预上び分析精度を求めクロム酸鉛法 による品位と比較すると Table V, Table VI に示す とおりで満足すべき結果が得られた. 分析所要時間注 2 〜 時間で操作はきわ放て簡単である. 
Table V 鉱石試料の定量結果

\begin{tabular}{|c|c|c|c|c|c|c|c|c|}
\hline \multirow{2}{*}{ 試 料 名 } & \multirow{2}{*}{$\begin{array}{c}\text { 採取量 } \\
(\mathrm{g})\end{array}$} & \multicolumn{3}{|c|}{ 第 1 法定量值 } & \multicolumn{3}{|c|}{ 第 2 法定量值 } & \multirow{2}{*}{$\begin{array}{c}\text { クロム酸鉛法 } \\
\text { 定量値 } \\
(\%)\end{array}$} \\
\hline & & 測定値 (\%) & 平均値 $(\%)$ & $\sigma$ & 測定值(\%) & 平均值(\%) & $\sigma$ & \\
\hline 鉛 原 鉱 & 1 & $\begin{array}{l}1.93 \\
1.95 \\
1.90 \\
1.90\end{array}$ & 1.90 & 0.02 & $\begin{array}{l}1.93 \\
1.90 \\
1.95 \\
1.90\end{array}$ & 1.92 & 0.02 & 1.90 \\
\hline 鉛 唅石 & 2 & $\begin{array}{l}0.20 \\
0.20 \\
0.19 \\
0.20\end{array}$ & 0.20 & 0.004 & $\begin{array}{l}0.21 \\
0.20 \\
0.20 \\
0.20\end{array}$ & 0.20 & 0.004 & 0.18 \\
\hline 鉛 精 鉱 & 0.2 & $\begin{array}{l}56.30 \\
56.30 \\
56.30 \\
56.62\end{array}$ & 56.38 & 0.138 & $\begin{array}{l}56.62 \\
56.62 \\
56.43 \\
56.30\end{array}$ & 56.49 & 0.135 & 56.49 \\
\hline 銅 精 铈 & 0.5 & $\begin{array}{l}3.27 \\
3.33 \\
3.37 \\
3.27\end{array}$ & 3.30 & 0.042 & $\begin{array}{l}3.38 \\
3.33 \\
3.27 \\
3.33\end{array}$ & 3.33 & 0.039 & 3.41 \\
\hline 两鉛精鉣 & 0.5 & $\begin{array}{l}1.36 \\
1.39 \\
1.41 \\
1.41\end{array}$ & 1.39 & 0.020 & $\begin{array}{l}1.41 \\
1.41 \\
1.41 \\
1.44\end{array}$ & 1.42 & 0.014 & 1.40 \\
\hline
\end{tabular}

Table VI 鉛製煉関係試料の定量結果

\begin{tabular}{|c|c|c|c|c|c|c|c|c|c|c|}
\hline \multirow{2}{*}{ 試 } & \multirow{2}{*}{\multicolumn{2}{|c|}{ 料 名 }} & \multirow{2}{*}{$\begin{array}{c}\text { 採取量 } \\
\text { (g) }\end{array}$} & \multicolumn{3}{|c|}{ 第 1 法定量值 } & \multicolumn{3}{|c|}{ 第 2 法定量值 } & \multirow{2}{*}{$\begin{array}{c}\text { クロム酸鉛法 } \\
\text { 定量値 } \\
(\%)\end{array}$} \\
\hline & & & & 測定值 (\%) & 平均值 $(\%)$ & $\sigma$ & 测定値 (\%) & 平均值 $(\%)$ & $\sigma$ & \\
\hline 焼 & & 鉱 & 0.2 & $\begin{array}{l}62.35 \\
62.35 \\
62.22 \\
62.22\end{array}$ & 62.29 & 0.065 & $\begin{array}{l}62.35 \\
62.47 \\
62.60 \\
62.35\end{array}$ & 62.44 & 0.103 & 62.48 \\
\hline 蟒 & & 塊 & 0.2 & $\begin{array}{l}53.15 \\
53.27 \\
53.40 \\
53.40\end{array}$ & 53.31 & 0.104 & $\begin{array}{l}53.27 \\
53.53 \\
53.53 \\
53.53\end{array}$ & 53.47 & 0.113 & 53.45 \\
\hline 鍰 & & & 1 & $\begin{array}{l}3.73 \\
3.78 \\
3.68 \\
3.78\end{array}$ & 3.74 & 0.041 & $\begin{array}{l}3.83 \\
3.73 \\
3.73 \\
3.78\end{array}$ & 3.77 & 0.041 & 3.87 \\
\hline 鈹 & & & 0.5 & $\begin{array}{l}21.86 \\
21.86 \\
21.86 \\
21.92\end{array}$ & 21.88 & 0.026 & $\begin{array}{l}21.92 \\
21.86 \\
21.97 \\
21.97\end{array}$ & 21.93 & 0.045 & 21.97 \\
\hline 分 銀 & 退密 B & 陀 & 0.5 & $\begin{array}{l}31.84 \\
31.89 \\
31.84 \\
31.79\end{array}$ & 31.84 & 0.027 & $\begin{array}{l}31.84 \\
31.89 \\
31.84 \\
31.89\end{array}$ & 31.87 & 0.025 & 31.49 \\
\hline 電解ス & スライ & & 0.5 & $\begin{array}{l}17.68 \\
17.73 \\
17.73 \\
17.78\end{array}$ & 17.76 & 0.035 & $\begin{array}{l}17.63 \\
17.68 \\
17.78 \\
17.73\end{array}$ & 17.76 & 0.061 & 17.41 \\
\hline 貴 & & 鉛 & 0.5 & $\begin{array}{l}21.31 \\
21.46 \\
21.36 \\
21.56\end{array}$ & 21.42 & 0.065 & $\begin{array}{l}21.51 \\
21.36 \\
21.61 \\
21.66\end{array}$ & 21.54 & 0.114 & 21.43 \\
\hline ア & $J-1$ & F & 0.2 & $\begin{array}{l}98.49 \\
98.62 \\
98.49 \\
98.62\end{array}$ & 98.56 & 0.065 & $\begin{array}{l}98.74 \\
98.87 \\
98.74 \\
98.62\end{array}$ & 98.74 & 0.088 & 98.88 \\
\hline 粗 & & 鉛 & 0.2 & $\begin{array}{l}98.37 \\
98.49 \\
98.62 \\
98.37\end{array}$ & 98.46 & 0.103 & $\begin{array}{l}98.74 \\
98.49 \\
98.62 \\
98.62\end{array}$ & 99.62 & 0.088 & 98.44 \\
\hline
\end{tabular}

\section{6 結 言}

硫酸鉛を酷酸アンモニウム抽出液で抽出した溶液に $\mathrm{Cu}-\mathrm{PAN}$ を指示薬として EDTA で滴定すれば明瞭か つ鋭敏な終点で滴定することができた．鉱石試料および
鉛製煉関係試料に適用し従来のクロム酸鉛法と比較して 分析精度, 正確度もよく迅速で満足すべき結果が得られ た。また EBT 指示薬を用いる場合よりさらに優れてい ることが認められた。 


\section{交献}

1) JIS M 8123.

2) W. W. Scott : “Standard Methods of Chemical Analysis", Vol. 1, 511 (1952).

3) 上野景平：“キレート滴定法”, 180 (1956), (南江堂).

4) J. L. Pinkston, C. T. Kenner : Anal. Chem., 27, 446 (1955).

5) K. L. Cheng, R. H. Bary : ibid., 27, 782 (1955).

6) 上野景平：“最新の分析化学”, 9, 89 (1958).

is

Determination of lead by titration with EDTA. Masanori HiSADA and Kaichi KASHIKAwA (Akenobe Mine, Mitsubishi Metal Mining Co., Ltd.)

A rapid, simple accurate method for a determination of lead was attempted by titration with EDTA using $\mathrm{Cu}-\mathrm{PAN}$ as an indicator.

Conditions for titration and for separation from the interfering substances were investigated, and a suitable procedure was established. The outline is as follows:

The sample was treated with $\mathrm{HNO}_{3}$ and $\mathrm{H}_{2} \mathrm{SO}_{4}$, and lead was precipitated as lead sulfate. After separating by filtration, the precipitate was dissolved in $\mathrm{NH}_{4} \mathrm{C}_{2} \mathrm{H}_{3} \mathrm{O}_{2}-\mathrm{HC}_{2} \mathrm{H}_{3} \mathrm{O}_{2}$ solution. The solution was boiled for a few minutes and titrated immediately with a standard solution of EDTA at about $\mathrm{pH} 5$ using $\mathrm{Cu}-\mathrm{PAN}$ as an indicator. The end point was noticed by a sharp change from red to yellow.

By this procedure, the interfering metals were removed with an exception of $\mathrm{Ba}, \mathrm{Ca}, \mathrm{W}$ and some insoluble matters. Ca does not interfere the determination at the proposed $\mathrm{pH}$. Since $\mathrm{Ba}$ and $\mathrm{W}$ both interfere and give lower values, they must be separated preliminarily from lead. The various samples can be analysed by this method with reliable results. The time required for an analysis is about $2 \sim 3$ hours.

(Received June 9, 1959)

\title{
EDTA を用いるコバルトのポーラログラフ分析法*
}

\author{
中川 元吉, 野村 毅**
}

\begin{abstract}
ボーラログラフ法によって銅，ニッケル，亜鉛などと共存するコバルトを定量する目的で EDTA 加えた支持電解質中で過酸化鉛号用いてコバルトを酸化し，生ずる Co(III)-EDTA キレート化合物の 還元波总利用してコバルト觉定量する方法について検討した. Co(III)-EDTA キレート化合物は $0 \mathrm{~V}$ (S. C. E.) 付近で Co(II) に還元されるポーラログラフ波なあらわし, 限界電流は拡散律速によるるの である. 使用する EDTAの濃度は 0.04〜0.06M が適当であり，電解夜の $\mathrm{pH} 8$ ～9 範囲で良好な ポーラログラフ波が得られた。

上記の条件でコバルトの濃度と波高の間には良好な比例性が認められた．銅，マンガン，ニッケル， 垔鉛などはコバルトの定量总妨害しない. 鉄, クロムはコバルトの定量を妨害する.多量の硫酸塩はコ バルトの波高省減少させる.
\end{abstract}

\section{1 緒言}

ボーラログラフ分析法によってコバルトを定量する場 合にはピリジン，チオシアン酸カリウム，アンモニアー 塩化アンモニウムなどの支持電解質が一般に用いられて (๖).

しかしながら上記支持電解質中ではいずれもコバルト と亜鉛のポーラログラフ波が重なるために，ボーラログ

* 錯化合物形成剤を使用するポーラログラフ分析法の 研究 (第 3 報)

** 名古屋工業大学工業化学科 : 名古屋市昭和区御器所 町
ラフ分析法の前に亜鉛をコバルトから分離しておかねば ならない。また多量のニッケルがコバルトと共存する場 合にもコバルトの定量は不可能となる.

錯化合物形成剤が存在する場合には，コバルトは適当 な酸化剂を用いることによって容易に 3 価のコバルト錯 化合物に酸化することができる.このさい生じたコバル ト (III) 錯化合物は 2 価のコバルトにくらべて正電位で 3 価から 2 価に還元されるポーラログラフ波をあらわす のでこの波を用いてコバルトを定量する方法が研究され ている.

Watters $^{2)}$ らはアンモニアー塩化アンモニウム溶液中 で過ホウ酸ナトリウムを用いてコバルトを酸化し，でき 